\title{
Development of mango flavored Soy Dahi
}

\author{
TA Rakhi* ${ }^{1}$, MN I slam ${ }^{1}$, SAM Hoque ${ }^{2}$, MM Rahman $^{3}$ \\ ${ }^{1}$ Department of Dairy Science, Bangladesh Agricultural University, Mymensingh 2202; ${ }^{2}$ Department of Animal \\ Breeding and Genetics, Bangabandhu Sheikh Muzibur Rahman Agricultural University, Gazipur 1706; \\ ${ }^{3}$ Department of Pharmacology, Bangladesh Agricultural University, Mymensingh 2202, Bangladesh
}

\begin{abstract}
The experiment was aimed to prepare mango flavored soy milk based dahi (whole cow milk : soy milk=1:1). To remove the beany flavour of soybean as well as to add the mango flavour, mango juice were added at the rate of $0,5,10$ and $15 \%$. Data on physical and chemical parameters were recorded and analyzed. It was observed that smell and taste, body and consistency, color and appearance as well as total score were significantly increased $(p<0.01)$ when $5 \%$ mango juice added to soy milk based dahi. These properties could further be increased significantly $(p<0.01)$ by increasing the level up to $10 \%$ but increasing the level of mango juice up to $15 \%$ were significantly decreased $(p<0.01)$ the physical properties. After chemical analysis, a significant increasing $(p<0.05)$ in acidity, total solids and carbohydrate content but a significantly decresing $(p<0.05)$ in fat and ash content of dahi were observed due to the addition of mango juice. Compilation of physico-chemical properties it was observed that addition of $10 \%$ mango juice prepared a high quality low cost mango flavored soy milk based dahi. Considering the shortage along with high price of milk we could transfer the techniques to the manufacturer to produce and market the mango flavored soy milk based dahi.
\end{abstract}

Key words: Mango juice, soybean, whole milk

Bangladesh Animal Husbandry Association. All rights reserved.

Bang. J. Anim. Sci. 2013. 42 (1): 44-48

\section{I ntroduction}

Due to shortage of milk and other protein rich food of animal origin in Bangladesh, the incidence of protein malnutrition is very high. For this purpose, low cost processed supplementary food need to be developed in Bangladesh and the product such as Soy milk and curd can play vital role. Soybean contains about $20 \%$ oil and the oil of soybean contain $85 \%$ unsaturated fatty acid and also no cholesterol, it is also rich in $\mathrm{Ca}$ and Vitamins A, B, C, and D (Rahman, 1982). Now a days different kinds of human foods are prepared from soybean such as Soy milk, Tofu, Ice cream, $\mathrm{Su} \mathrm{Fu}$, Beverage etc. Occurance of light beany flavour of soymilk is not accepted by general people and it can be improved by adding different flavors. The preparation of yoghurt (dahi) has been investigated by a number of researchers in different parts of the world (Desai et al. 1994 and Shukla et al. 1987). But in Bangladesh very limited work has yet been done on the preparation of fruit dahi. For these instances, this experiment is very important in present condition because the people of our country have no idea about this new food product. Keeping the aforesaid reality in mind the present study was undertaken to prepare mango flavored soy milk based high quality Dahi.

\section{Materials and Methods}

Whole milk was collected from Bangladesh Agricultural University (BAU) Dairy Farm and soybean seeds were collected from Department of Genetics \& Plant Breeding, BAU Mymensingh.

\section{Soy milk from soybean powder}

$1000 \mathrm{~g}$ whole soybean seed free from immature field damage and black spot were grinded in a soy flour mill. $125 \mathrm{~g}$ powder was dissolved with 1000 $\mathrm{ml}$ of water by stirring. The soy milk was strained through a fine cloth to separate the residue. Soy milk was then boiled at $100^{\circ} \mathrm{C}$ for $10-15$ minutes with constant stirring.

\section{Preparation of mango juice}

The mango fruit was washed by distilled water, skin was separated, seeds were removed and the fruit pulp was blended. After blending the juice was filtered by clean cloth and stored at refrigeration temperature $\left(4^{\circ} \mathrm{C}\right)$ until preparation of Dahi.

\section{Chemical tests and analysis of cow's milk and soy milk}

Before preparation of various types of Dahi the initial chemical quality of cow milk and soy milk was analyzed in terms of specific gravity, acidity 
$(\%), \mathrm{pH}$, total solids (\%), moisture (\%), fat (\%), protein $(\%)$, carbohydrate (\%) and ash (\%) in the laboratory.

\section{Preparation of different types of Dahi}

The Dahi ware prepared by adding the starter culture (at the rate of $2 \%$ ) to the mixed milk collected from local market and dissolved properly by stirring. The milk was then poured in several pre-boiled water washed plastic cups of about $100 \mathrm{ml}$ size and kept at an incubation temperature of $42^{\circ} \mathrm{C}$ for 4 hours for complete coagulation of the samples. After complete coagulation, the Dahi samples were taken out from the incubator and were stored in a refrigerator at $5^{\circ} \mathrm{C}$ for analytical purpose. This type of Dahi was identified as 'A' type (control) Dahi for experimental purpose. Mango juice was taken out from the refrigerator and kept in the room temperature for melting. The mango juice was divided into three portions in different levels like 5,10 and $15 \%$ level in three different beakers. Different levels of mango juice were added to the mixed milk samples of $50 \%$ whole cow milk and $50 \%$ soy milk and mixed properly with the help of the spoon. Juice was added before incubation with culture as suggested by Gandhi et al. (1977), Singh (1979) and De (1985). The starter culture was added to the mixed milk collected from local market and dissolved properly by stirring it. Then the milk was poured in several pre-boiled water washed plastic cups of about $100 \mathrm{ml}$ size and then Dahi was prepared by using the same procedure used for making cow milk Dahi. These different types of Dahi were identified as ' $B$ ', ' $C$ ' and ' $D$ ' types of Dahi for the experimental purpose. Thus four types of Dahi were prepared in this experiment using whole cow milk, soy milk and mango juice as: Type $A$ \{ $100 \mathrm{ml}$ mixed milk (50\% whole cow milk $+50 \%$ Soy milk) $\}$ as control; Type B $\{95 \mathrm{ml}$ mixed milk $(50 \%$ whole cow milk $+50 \%$ Soy milk) $+5 \mathrm{ml}$. Mango juice $\}$; Type $C\{90 \mathrm{ml}$ mixed milk $(50 \%$ whole cow milk $+50 \%$ Soy milk $)+10$ $\mathrm{ml}$. Mango juice); Type $\mathrm{D}\{85 \mathrm{ml}$ mixed milk $(50 \%$ whole cow milk $+50 \%$ Soy milk $)+15 \mathrm{ml}$. Mango juice).

\section{Evaluation of different types of Dahi sample}

Organoleptic parameters on the physical tests (sensory evaluation) measured by expert judges were as: i. Smell and taste score - 50; ii. Body and consistency score -30; iii. Color and appearance score - 20; iv. Overall score- 100.

\section{Chemical tests and analysis of Dahi}

For certifying the nutritional status the samples were evaluated in various ways. After the organoleptic evaluations, all Dahi samples were chemically analyzed in the laboratory in terms of specific gravity, acidity (\%), $\mathrm{pH}$, total solids (\%), moisture $(\%)$, fat $(\%)$, protein $(\%)$, carbohydrate (\%) and ash (\%).

\section{Statistical analysis}

All experimental materials were completely homogenous and statistical analysis was done as per Steel and Torrie (1960) by using Completely Randomized Design having four (4) treatment with three (3) replication for each.

\section{Results and Discussion}

\section{I nitial quality of cow's milk}

The flavour, appearance and colour of the milk sample was normal. Average specific gravity, moisture $(\%)$, total solids $(\%)$, fat $(\%)$, solodsnot-fat $(\%)$, protein $(\%)$, carbohydrate $(\%)$, ash (\%) and acidity (\%) were 1.031 \pm 0.002 , $88.12 \pm 0.304, \quad 11.88 \pm 0.30, \quad 4.00 \pm 0.10, \quad 7.88 \pm$ $0.21,3.44 \pm 0.07,3.72 \pm 0.18,0.71 \pm 0.02$ and 0.13 \pm 0.01 , respectively (Table- 1 ). The initial specific gravity and the chemical analysis of milk samples in this study were in accordane with the the normal range found in different literatures (Eckles et al. 1951, Jenness and Patton 1959, Rangappa and Achaya 1971 and Biswas 1997).

\section{I nitial quality of soy milk}

The specific gravity, acidity (\%), moisture (\%) and carbohydrate (\%) of experimental soy milk sample were $1.023 \pm 0.002,0.136 \pm 0.009$, $90.69 \pm 0.38$ and $2.28 \pm 0.41$, respectively (Table$1)$. The results was similar with the findings of Tuli (2007) who observed the specific gravity, acidity (\%), moisture (\%) and carbohydrate (\%) of mango juice were $1.024,0.133,90.98$ and 2.59, respectively. The total solids and ash content of soy milk samples were $9.31 \pm 0.38$ (\%) and $0.71 \pm 0.02$, respectively (Table 1 ). The result obtained by Katara and Bhargava (1994), as $10.59 \%$ total solids and $0.73 \%$ ash in soy milk sample was almost similar to our study. The average percentage of fat and protein of experimental soy milk was $2.48 \pm 0.08$ and $3.86 \pm 0.01$, respectively which were almost similar with the result of Swarninathan and Bhagavan (1966) who observed the $2.50 \%$ fat and $4.20 \%$ protein in soy milk. 
Mango flavored Soy Dahi

Table 1. Chemical quality of Cow's Milk, soy milk and mango juice sample

\begin{tabular}{lcccccccc}
$\begin{array}{l}\text { Types of } \\
\text { Milk/Juice }\end{array}$ & $\begin{array}{c}\text { Specific } \\
\text { gravity }\end{array}$ & $\begin{array}{c}\text { Acidity } \\
(\%)\end{array}$ & $\begin{array}{c}\text { Moisture } \\
(\%)\end{array}$ & $\begin{array}{c}\text { Total solids } \\
(\%)\end{array}$ & $\begin{array}{c}\text { Fat } \\
(\%)\end{array}$ & $\begin{array}{c}\text { Protein } \\
(\%)\end{array}$ & $\begin{array}{c}\text { Ash } \\
(\%)\end{array}$ & $\begin{array}{c}\text { CHO } \\
(\%)\end{array}$ \\
\hline \multirow{2}{*}{ Cow Milk } & 1.031 & 0.130 & 88.120 & 11.88 & 4.00 & 3.44 & 0.71 & 3.72 \\
& \pm 0.002 & \pm 0.012 & \pm 0.304 & \pm 0.300 & \pm 0.101 & \pm 0.073 & \pm 0.017 & \pm 0.179 \\
Soy milk & 1.023 & 0.136 & 90.690 & 9.310 & 2.480 & 3.863 & 0.710 & 2.280 \\
& \pm 0.002 & \pm 0.009 & \pm 0.381 & \pm 0.377 & \pm 0.082 & \pm 0.013 & \pm 0.023 & \pm 0.411 \\
Mango juice & - & - & 84.19 & 15.52 & 1.53 & 3.58 & 3.30 & 7.11 \\
& & & \pm 0.08 & \pm 0.03 & \pm 0.02 & \pm 0.15 & \pm 0.01 & \pm 1.25 \\
\hline
\end{tabular}

Source: Laboratory of Dairy Science, Bangladesh Agricultural University, Mymensingh-2202, Bangladesh

Table 2. Summary of the results of physical evaluation of different Dahi samples

\begin{tabular}{|c|c|c|c|c|c|c|}
\hline \multirow{2}{*}{ Parameters } & \multicolumn{4}{|l|}{ Types of Dahi } & \multirow{2}{*}{$\begin{array}{l}\text { LSD } \\
\text { Value }\end{array}$} & \multirow{2}{*}{$\begin{array}{l}\text { Sig. } \\
\text { level }\end{array}$} \\
\hline & A & $\mathrm{B}$ & $\mathrm{C}$ & $\mathrm{D}$ & & \\
\hline Smell and Taste & $39.67^{c} \pm 0.33$ & $42.00^{b} \pm 0.58$ & $45.33^{a} \pm 0.33$ & $41.33 b^{c} \pm 0.67$ & 2.25 & $* *$ \\
\hline Body and consistency & $22.67^{c} \pm 0.33$ & $24.00^{b} \pm 0.58$ & $26.33^{a} \pm 0.67$ & $22.00^{c} \pm 0.58$ & 1.31 & $* *$ \\
\hline Color and appearance & $15.67^{\mathrm{bc}} \pm 0.33$ & $16.33^{b} \pm 0.33$ & $18.00^{a} \pm 0.58$ & $15.33^{c} \pm 0.33$ & 0.98 & $* *$ \\
\hline Total score & $78.00^{c} \pm 0.58$ & $82.33^{\mathrm{b}} \pm 0.67$ & $89.67^{a} \pm 0.88$ & $78.67^{c} \pm 1.33$ & 3.12 & $* * *$ \\
\hline
\end{tabular}

Figures within the same row with different superscripts differ significantly; $*, p<0.05 ; * * *, p<0.001 ;$ NS, non significant; A, $50 \%$ cow milk $+50 \%$ soy milk; B, $50 \%$ Cow milk $+50 \%$ soy milk $+5 \%$ mango juice; C, $50 \%$ cow milk $+50 \%$ soy milk+10\% mango juice; $D, 50 \%$ cow milk $+50 \%$ soy milk $+15 \%$ mango juice

Table 3. Summary of the results of chemical evaluation of different Dahi samples

\begin{tabular}{|c|c|c|c|c|c|c|}
\hline \multirow[t]{2}{*}{ Parameters } & \multicolumn{4}{|l|}{ Types of Dahi } & \multirow{2}{*}{$\begin{array}{l}\text { LSD } \\
\text { value }\end{array}$} & \multirow{2}{*}{$\begin{array}{l}\text { Sig. } \\
\text { level }\end{array}$} \\
\hline & $A$ & B & $\mathrm{C}$ & $\mathrm{D}$ & & \\
\hline Acidity (\%) & $0.76^{b} \pm 0.04$ & $0.81^{b} \pm 0.03$ & $0.87^{\mathrm{ab}} \pm 0.02$ & $0.92^{\mathrm{a}} \pm 0.01$ & 0.12 & * \\
\hline $\mathrm{pH}$ & $4.24 \pm 0.06$ & $4.17 \pm 0.04$ & $4.13 \pm 0.04$ & $4.07 \pm 0.02$ & 0.67 & NS \\
\hline Fat (\%) & $4.52^{a} \pm 0.08$ & $4.42^{\mathrm{ab}} \pm 0.06$ & $4.33^{\mathrm{ab}} \pm 0.03$ & $4.21^{b} \pm 0.01$ & 0.23 & $*$ \\
\hline Total solids (\%) & $22.38^{\mathrm{C}} \pm 0.19$ & $23.39^{b} \pm 0.09$ & $23.76^{b} \pm 0.06$ & $26.19^{a} \pm 0.10$ & 0.55 & $* * *$ \\
\hline Moisture (\%) & $77.62^{a} \pm 0.19$ & $76.61^{b} \pm 0.09$ & $76.24^{b} \pm 0.06$ & $73.81^{c} \pm 0.10$ & 0.55 & $* * *$ \\
\hline Ash (\%) & $0.86^{b} \pm 0.02$ & $0.89^{\mathrm{ab}} \pm 0.02$ & $0.94^{\mathrm{ab}} \pm 0.02$ & $0.96^{\mathrm{a}} \pm 0.02$ & 0.08 & $*$ \\
\hline Protein (\%) & $4.40 \pm 0.26$ & $4.30 \pm 0.24$ & $4.21 \pm 0.21$ & $4.16 \pm 0.21$ & 1.05 & NS \\
\hline $\mathrm{CHO}(\%)$ & $12.51^{c} \pm 0.41$ & $13.74^{b c} \pm 0.36$ & $14.33^{b} \pm 0.28$ & $16.96^{\mathrm{a}} \pm 0.11$ & 1.40 & $* * *$ \\
\hline
\end{tabular}

Figures within the same row with different superscripts differ significantly; $*, \mathrm{p}<0.05 ; * * *, \mathrm{p}<0.001 ; \mathrm{NS}$, non significant; A, $50 \%$ cow milk $+50 \%$ soy milk; B, $50 \%$ Cow milk $+50 \%$ soy milk $+5 \%$ mango juice; C, $50 \%$ cow milk $+50 \%$ soy milk $+10 \%$ mango juice; $D, 50 \%$ cow milk $+50 \%$ soy milk $+15 \%$ mango juice

\section{I nitial quality of mango juice}

The initial moisture (\%) and total solids (\%) of mango juice were $84.19 \pm 0.08$ and $15.52 \pm 0.03$ which were almost similar with Ramulu and Rao (2003) who observed $85.23(\%)$ moisture in the mango juice. The fat $(\%)$, protein (\%), Carbohydrate (\%) and ash (\%) of prepared mango juice were $1.53 \pm 0.02,3.58 \pm 0.15$, $7.11 \pm 1.25$ and $3.30 \pm 0.01$, respectively (Table$1)$. The results were in accordance with the results of Ibrahim et al. (2010) who observed $1.75 \%$ fat, $3.78 \%$ protein, $7.61 \%$ carbohydrate and $3.30 \%$ ash in mango juice.

\section{Quality of Dahi}

\section{Physical parameter}

The score of smell and taste, body and consistency, color and appearance as well as the total score of different types Dahi were compiled in Table 2. It was observed that the individual and total score of physical parameters were significantly increased $(p<0.01)$ when $5 \%$ mango juice added to soy milk based Dahi. These properties could further be increased significantly $(p<0.01)$ by increasing the level up to $10 \%$ but increasing the level of mango juice up to $15 \%$ significantly decreased $(p<0.01)$ the physical properties. As carbohydrate content of mango 
juice is high ( $7.11 \%)$, it's addition up to $10 \%$ developed acceptable physical properties in Dahi. But further addition made the thicker, more yellow color and extreme sweet taste. The decreasing nature of physical properties at the rate $15 \%$ might be due to that causes. The result of this experiment agrees with the work of Desai et al. (1994) who found that physical properties of mango and pineapple yogurts were higher than that of control Dahi. Mustafa (1997) and Keating and White (1991) also found that the addition of fruit juice improved physical properties of Dahi.

\section{Chemical parameters}

The acidity (\%), pH, total solids (\%), moisture $(\%)$, fat $(\%)$, protein $(\%)$, carbohydrate (\%) and ash $(\%)$ of the prepared Dahi were compiled in Table-3. It was observed that acidity, total solids, carbohydrate and ash content of Dahi were significantly increased $(p<0.05)$ but fat content is significantly decresed $(p<0.05)$ due to the addition of mango juice. Generally fruit contains low level of fat and high level of carbohydrates and ash. Therefore the variation might come from chemical composition of mango juice. The $\mathrm{pH}$ value and protein content were unchanged. The results of the study agrees with the findings of Desai et al. (1994) and Mustafa (1997) who found that the titratable acidity, total solids, carbohydrate and ash content of fruit Dahi was significantly increased due to the addition of fruit juice/plup. They also stated that the fat content of fruit juice Dahi might be decresed depending on the fat content of fruit. Sarker et al. (1996) studied the acidity content of plain misti Dahi from different districts of West Bengal and found that acidity percent was within the range of 0.36 to $1.17 \%$ with an average value of 0.92 percent. Sultana (2005) found that moisture content of Dahi sample decreased due to addition of different levels of mango juice which agrees with our findings (Table-3). Total solids content of plain misti Dahi was studied by Sarkar et al. (1996) and reported that average total solids content of Dahi collected from different districts of West Bengal was within the range of 29.5 to $52.30 \%$ with an average value of $40.27 \%$. Ghosh and Rajorhia (1987) observed that solids content of plain market Dahi varied from 26.92 to $43.04 \%$ with an average value of 34.64 percent. Total solids content Dahi from our experiment was agreed with the above results.

\section{Conclusion}

From this study, it is clear that addition of mango juice to Soy Dahi increasing the physical quality but somewhat deviation occures in case of chemical properties. Considering the acute shortage along with high price of milk this chemical changes might be acceptable for developing mango flavored soy based Dahi.

\section{References}

Biswas AA. (1997). Effect of Banana (Musa sapientum) leaf on quality of raw milk. M.S. Thesis, Department of Dairy Science, Bangladesh Agricultural University, Mymensingh.

De S (1985). Outlines of Dairy Technology. Oxford University Press, New Delhi.

Desai SR, Toro VA, Josh SV (1994). Utilization of different fruit in the manufacture of yoghurt. Indian Journal of Dairy Science, 47: 870-874.

Eckles $\mathrm{CH}$, Combs WB, Macy H (1951). Milk and Milk Products. $4^{\text {th }}$ edition, McGraw- Hlill Book Company, New York, P. 48.

Gandhi DN, Madanlal MS, Nambudripad VKN (1977). Development of low-cost milk product for the people of Uttarprodesh. Indian Journal of dairy science, 156: 255258.

Ghosh J, Rojorhia GS (1987). Chemical microbiological and sensory properties of with misti dahi in Calcutta. Asian Journal of Dairy Research, 6: 11-18

Ibrahim M, Prasad KN, Ismail A, Azlan A, Abd AH (2010). Physiochemical composition and antioxidant activities of underutilized Mangifera pajang fruit. African Journal of Biotechnology, 9: 4392-4397.

Jenness R, Patton S (1959). Principles of Dairy Chemistry. John Wiley and Sons, London, P. 97-98.

Katara RV, Bhargava VN (1994). Studies of the manufacture of rasogolla from buffalo milk and soy milk blends. Indian J ournal of Dairy Science, 47: 981-986.

Keating KR, White $\mathrm{CH}$ (1991). Effect of alternative sweeteners in plain and fruit flavored yoghurts. Journal of Dairy Science, 73: 54-62.

Mustafa MMH (1997). A study on the preparation of fruit dahi (yoghurt). M.S. Thesis, Department of Dairy Science, Bangladesh Agricultural University, Mymensingh.

Rahman M (1982). A comparative study on cows and buffaloes milk and their shelf life at room and refrigeration temperature. MS Thesis, Department of Dairy Science. Bangladesh Agricultural University, Mymensingh. 
Ramulu P, Rao PU (2003). Total, insoluble and soluble dietary fiber contents of Indian fruits. Journal of Food Composition and Analysis. 16: 677-685.

Rangappa KS, Achaya KT (1971). Indian Dairy Products $\left(2^{\text {nd }}\right.$ edition). Asia Publishing House, Bombay, India. P. 119-124.

Sarkar RK, Kuila AK, Misra T (1996). Orgnoleptic, Microbiological and Chemical quality of misti dahi sold in different districts of West Bengal. Indian J ournal of Dairy Science, 49: 1-6.

Shukla FC, Jain SC, Sandha KS (1987). Technological and physical chemical aspects of yoghurt and fruit yoghurt. Indian J ournal of Dairy Science, $90: 1-7$

Singh S (1979). Paneer like product from nonconventional solids-a review Division of
Dairy technology, NDRT, Karnal, India. Indian Journal of Dairy Science, 47: 245256.

Steel RDG, Torrie JH (1980). Principles and procedures of statistics: a biometrical approach. New York: McGraw-Hill Book, P. 477-494.

Sultana N (2005). Preparation of dahi from buffalo milk with the addition of different levels of soy milk. M.S. Thesis, Department of Dairy Science. Bangladesh Agricultural University, Mymensingh.

Swarninathan M, Bhagavan RK (1966). "Our food" Ganensh and Co. Madras-17, India, P. 170

Tuli WA (2007). Preparation of soy milk by using different methods. MS Thesis, Department of Dairy Science, Bangladesh Agricultural University, Mymensingh. 